\title{
Peningkatan Pendapatan Kelompok Pengrajin Arang Batok Kelapa Maju Adil Makmur Melalui Produksi Asap Cair Berkualitas Tinggi Untuk Mendukung Program Biogasoline
}

\author{
Sukamta1,*, Sudarja', Cahya Tresna Pradana1, Syamsiro² \\ ${ }^{1}$ Program Studi Teknik Mesin, Fakultas Teknik, Universitas Muhamamdiyah Yogyakarta, Jl. Brawijaya, Tamantirto, kasihan, Bantul, Yogyakarta, \\ Kode Pos 55183, Telepon o8157998996. \\ 2Universitas Janabadra Yogyakarta, Jl. Tentara Rakyat Mataram No.58, Bumijo, Kec. Jetis, Kota Yogyakarta, Daerah Istimewa Yogyakarta 55231 \\ *Korespondensi : sukamta@umy.ac.id \\ DOI: $10.18196 / p p m \cdot 31.134$
}

\begin{abstract}
Abstrak
Kelompok pengrajin arang batok kelapa "Maju Adil Makmur" yang berada di Dusun Murangan 7, Desa Triharjo, Kecamatan Sleman, Kabupaten Sleman, Daerah Istimewa Yogyakarta. Permasalahan utama yang dihadapi adalah asap yang dihasilkan dari proses produksi ini berpotensi mengganggu lingkungan karena jumlahnya yang banyak. Untuk itulah maka dikembangkan metode destilasi yang memproses asap menjadi cairan, yang kemudian disebut asap cair. Namun demikian, asap cair yang dihasilkan masih bercampur dengan abu (fly ash), sehingga harganya rendah. Oleh karena itu, telah dilakukan proses pengolahan kembali asap cair tersebut dengan metode destilasi tingkat lanjut untuk menghasilkan asap cair kualitas tinggi (grade A) sehingga harganya meningkat. Hasilnya, pengerajin mampu menghasilkan asap cair dengan kualitas yang jauh lebih baik daripada sebelumnya. Jika sebelumnya asap cair yang dihasilkan hanya mampu dijual dengan harga Rp 6.000,00 per liter, setelah dilakukan proses destilasi tingkat lanjut maka dihasilkan asap cair kualitas tinggi yang dinamakan grade A, dan mampu dijual dengan harga Rp 28.000,00 per liter atau telah mengalami peningkatan pendapatan yang cukup signifikan yaitu sebesar 4 kali lebih besar.
\end{abstract}

Kata Kunci: Asap; batok; cair; kelapa; pendapatan

\section{Pendahuluan}

Kelompok pengrajin arang batok kelapa "Maju Adil Makmur" berada di Dusun Murangan, Triharjo, Sleman, Yogyakarta berdiri sejak tahun 2015. Manajemen pengelolaan usaha masih bersifat konvensional dan belum melibatkan teknologi modern. Kelompok ini hanya memiliki dua buah tungku yang dipakai memproses batok kelapa menjadi arang dengan kapasitas pengolahan batok kepala setiap tungku adalah $0.5 \mathrm{Ton} /$ hari atau 1 Ton/hari batok kelapa untuk kedua tungku tersebut. Setiap pengolahan 3,5 Ton batok kelapa menghasilkan 1 Ton arang. Gambar situasi mitra yaitu kelompok pengrajin "Maju Adil Makmur" dapat dilihat pada gambar 1.

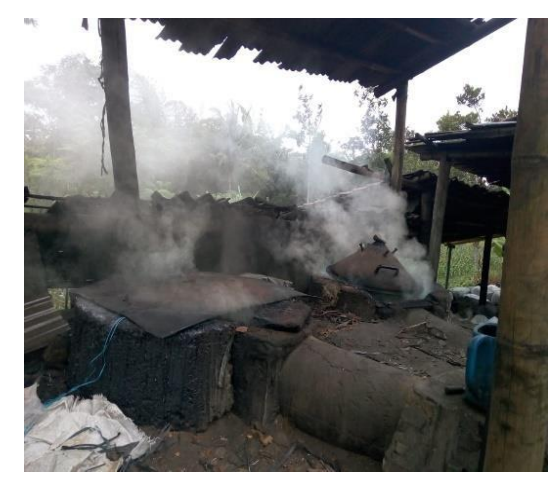

(a)

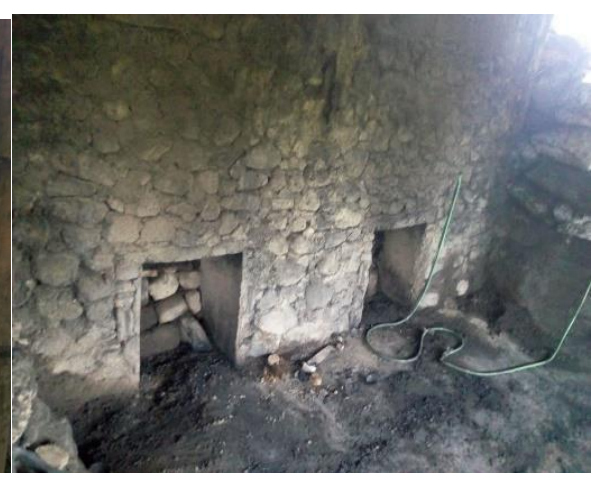

(b)

Gambar 1. (a). Tungku proses produksi dilihat dari depan, (b). Tungku sedang beroperasi dilihat dari bagian atas. 
Untuk satu kali proses produksi membutuhkan waktu kurang lebih 16 jam, sehingga dalam satu hari hanya dapat beroperasi satu kali untuk setiap tungku. Kelompok ini memiliki dua buah tungku sehingga dalam satu hari dapat melakukan proses produksi dengan dua tungku secara bersamaan. Selama ini mulai dari mencari bahan baku, proses produksi, dan penjualan sudah berjalan, namun belum efektif sehingga hasilnya belum dapat maksimal. Kemampuan manajemen ketua kelompok dan anggota kelompok juga relatif rendah karena rerata hanya memiliki latarbelakang pendidikan sekolah menengah pertama dan atas.

Sementara itu, peneliti sebelumnya telah melakukan penjernihan asap cair dengan menggunakan arang aktif[1]. Peneliti ini membuat arang aktif dari tempurung kelapa dan untuk mengujinya maka digunakan untuk penjernihan asap cair hasil pirolisis. Dari penjernihan asap cair hasil pirolisis yang berwarna coklat keruh pengaruh arang aktif adalah pada pengurangan bau yang sangat menyengat dan penurunan $\mathrm{pH}$. Kekeruhan semakin bertambah karena cukup banyak ada sebagaian kotoran larut dalam asap cair. Sebenarnya penggunaan arang aktif pada asap cair adalah pada asap cair yang sudah dijernihkan dengan cara destilasi, bukan asap cair hasil langsung pirolisis karena keasamannya yang sangat tinggi. Di sisi lainnya, penelitian tentang Pemanfaatan Asap Cair Tempurung Kelapa Sebagai Pestisida Organik Terhadap Mortalitas Ulat Grayak (Spodoptera Litura F.) telah dilakukan[2]. Penelitian ini bertujuan untuk mengetahui pengaruh konsentrasi asap cair tempurung kelapa terhadap mortalitas terhadap ulat grayak. Asap cair diperoleh melalui proses pirolisis. Hasil pirolisis yang didapatkan asap cair grade 3 yang digunakan sebagai pestisida organik pada ulat grayak dengan varian konsentrasi yang digunakan yaitu 1, 3, 5 dan 7\%. Hasil penelitian menunjukan bahwa asap cair tempurung kelapa dengan konsentrasi $7 \%$ memiliki presentasi mortalitas ulat grayak sebesar $88,89 \%$. Di samping itu, penelitian yang menguji keamanan penggunaan asap cair untuk produk pangan juga telah dilakukan oleh Budijanto dkk[3]. Sementara, terdapat penelitian sebelumnya yang fokus pada pengaruh penambahan asap cair tempurung kelapa destilasi dan redestilasi terhadap sifat kimia, mikrobiologi dan sensoris ikan pindang selama penyimpanan. Pada karakteristik sensoris (warna, aroma, tekstur, dan keseluruhan) ikan pindang dengan perlakuan asap cair redestilasi lebih disukai daripada perlakuan asap cair destilasi. Ditinjau dari sifat kimia, mikrobiologi, dan sensoris perlakuan asap cair redestilasi berbeda nyata dengan perlakuan asap cair destilasi. Peninjauan terhadap sifat kimia dan mikrobiologi perlakuan asap cair redestilasi $35 \%$ adalah perlakuan yang paling baik, sedangkan dari sifat sensoris perlakuan asap cair redestilasi $30 \%$ paling disukai oleh panelis dibandingkan perlakuan yang lainnya[4]. Telah dilakukan pula penelitian yang membandingkan karakteristik fisik (tekstur), kimia (kadar air, pH, TVB, fenol), dan organoleptik (tekstur, warna, aroma, keseluruhan) ikan tongkol dengan menggunakan pengawet asap cair dan $\mathrm{H}_{2} \mathrm{O}$. Pada karakteristik organoleptik (tekstur, aroma dan keseluruhan) ikan tongkol dengan perlakuan asap cair lebih disukai daripada perlakuan $\mathrm{H}_{2}$, sedangkan pada parameter warna ikan tongkol dengan perlakuan $\mathrm{H} 2 \mathrm{O}$ lebih disukai daripada perlakuan asap cair. Konsentrasi asap cair 25\% mampu menyamai konsentrasi H 3\% [5].

Di sisi lain, asap yang dihasilkan dari proses produksi ini berpotensi mengganggu lingkungan karena jumlahnya yang banyak. Untuk itu telah dilakukan proses pencairan asap berbentuk gas menjadi cair, yang kemudian disebut asap cair. Namun demikian, asap cair yang dihasilkan masih bercampur dengan abu (fly ash), sehingga harganya murah. Jika dapat mengolahnya kembali menjadi asap cair kualitas tinggi (grade A) maka harga menjadi jauh lebih tinggi. Hal inilah permasalahan yang masih dihadapi oleh pengrajin arang batok kepala "Maju Adil Makmur". Untuk itu sangat perlu dilakukan peningkatan manajemen dengan menerapkan standar kualitas terhadap produk asap cair dan melakukan peningkatan pendapatan melalui produksi asap cair berkualitas tinggi (grade A) untuk mendukung program biogasoline. 


\section{Metode Pelaksanaan}

Kelompok Pengrajin Arang Batok Kelapa "Maju Adil Makmur" bergerak di bidang ekonomi produktif, oleh karena itu maka metode pelaksanaan kegiatan terkait dengan tahapan pada 2 (dua) bidang permasalahan yang berbeda yang ditangani pada satu mitra, yaitu permasalahan produksi dan permasalahan manajemen (manajemen bahan baku, manajemen proses produksi, manajemen packing dan pergudangan, manajemen pengiriman, manajemen penjaminan mutu produk, dan manajemen pemasaran). Untuk itu perlu dilakukan metode pelaksanaan yang meliputi Penyuluhan, pelatihan, pendampingan teknis dan manajemen, pengukuran keberhasilan, dan monitoring serta evaluasi keberhasilan dan kendala. Penyuluhan kepada kelompok pengrajin agar bertambah wawasannya dan kemudian mau mengadopsi ide perbaikan ini. Pelatihan proses produksi arang batok kelapa berkualitas, produksi asap cair, penjaminan kualitas produk dan pelatihan manajemen. Pendampingan pembuatan asap cair kepada pengrajin agar mampu menghasilkan asap cair berkualitas tinggi (grade A). Pendampingan manajemen mulai dari manajemen bahan baku, manajemen proses produksi, manajemen packing dan pergudangan, manajemen pengiriman, manajemen penjaminan mutu produk, dan manajemen pemasaran. Pengukuran keberhasilan implementasi program. Hal ini penting untuk mengetahui seberapa berhasil program dan kegiatan yang telah dilakukan, apakah sesuai dengan rencana atau tidak, apa saja kendala yang dihadapi dan apa rencana tindaklanjutnya. Monitoring dan evaluasi dilakukan untuk memastikan bahwa implementasi program dapat berjalan dengan baik dan mampu memberikan dampak signifikan kepada pertumbuhan pengrajin.

\section{Hasil dan Pembahasan}

Pelaksanaan kegiatan terkait dibagi dalam 2 (dua) bidang permasalahan yang berbeda yang ditangani pada satu mitra, yaitu permasalahan produksi dan manajemen. Penyuluhan dilakukan kepada kelompok pengrajin agar bertambah wawasannya dan kemudian mau mengadopsi ide perbaikan ini. Penyuluhan kepada kelompok pengrajin arang batok "Maju Adil Makmur" telah dilaksanakan di rumah ketua kelompok yang beralamat di dusun Murangan 7, desa Triharjo, Kecamatan Sleman, Kabupaten Sleman, Daerah Istimewa Yogyakarta, seperti ditunjukkan pada gambar 2.

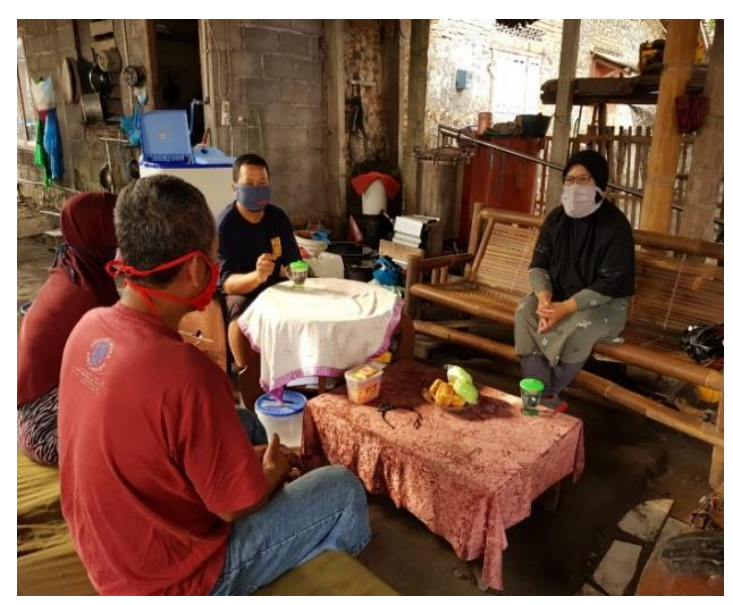

Gambar 2. Sosialisasi dan Penyuluhan

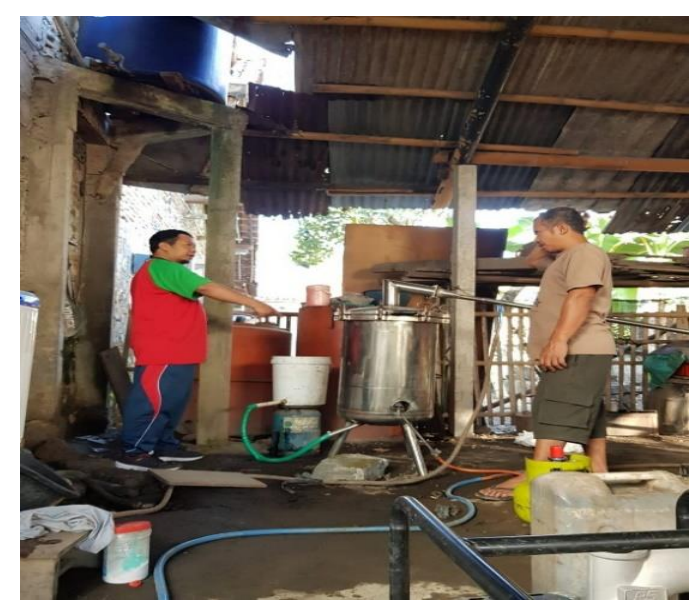

Gambar 3. Pelatihan pembuatan asap Cair 
Selanjutnya, pelatihan proses produksi arang batok kelapa berkualitas, asap cair, penjaminan kualitas produk dan pelatihan manajemen. Kemudian dilakukan pelatihan proses produksi asap cair, dan pelatihan penjaminan kualitas produk, serta pelatihan manajemen seperti ditunjukkan pada gambar 3. Pendampingan kepada pengrajin agar mampu menghasilkan asap cair berkualitas (grade A), seperti ditunjukkan pada gambar 4.

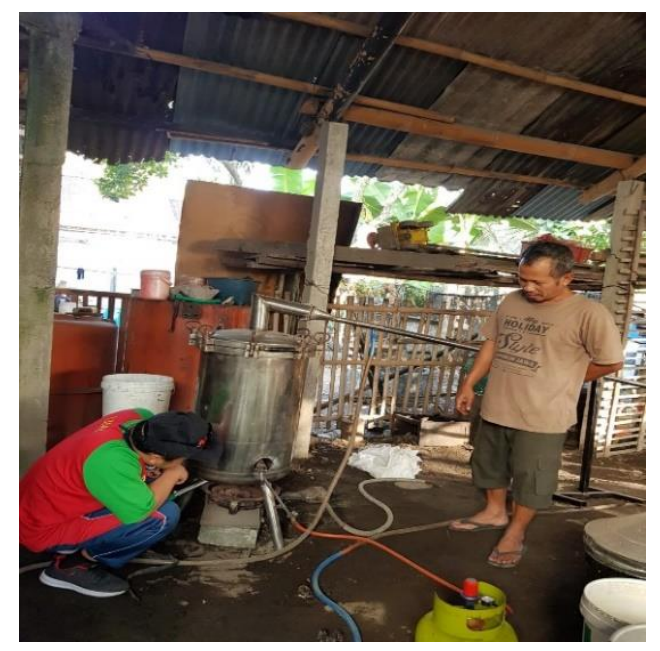

(a)

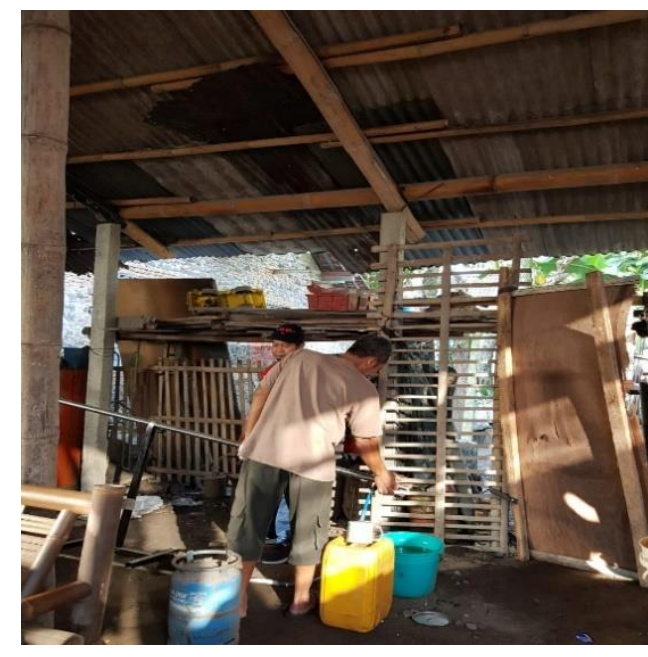

(b)

Gambar 4. Pendampingan pembuatan asap cair, meliputi a). Pengecekan fungsi Tungku pemanasan sap cair kualitas rendah b). Penyulingan asap cair kualitas rendah untuk menghasilkan asap cair kualitas tinggi (grade $A$ ).
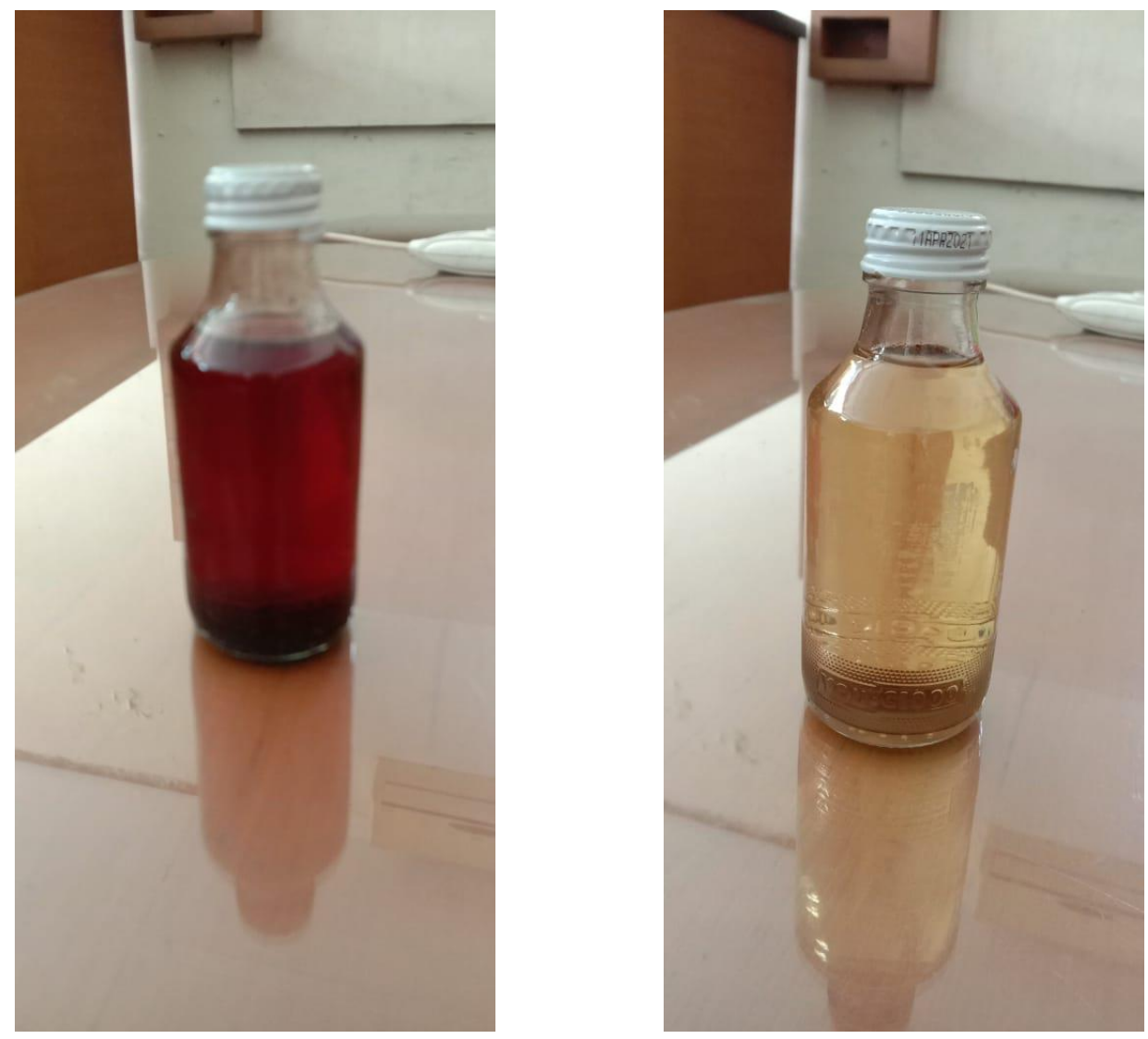

Gambar 5. a). asap cair sebelum diproses penyulingan, b). asap cair setelah melalui proses penyulingan 
Hasil penyulingan asap cair dapat dilihat pada gambar 5. Dari gambar tersebut dapat dijelaskan bahwa setelah proses penyulingan sebanyak satu kali, ternyata menghasilkan asap cair yang jauh lebih jernih dan lebih berkualitas, sehingga meningkatkan nilai harga jual sampai dengan kurang lebih 4 kali lebih tinggi. Telah dilakukan penelitian untuk mengetahui metode dan konsentrasi pemberian asap cair pada bakso ikan tenggiri yang memiliki tingkat kesukaan paling tinggi, mengetahui karakter sensoris (warna, aroma asap, rasa asap, kekenyalan dan keseluruhan) serta untuk mengetahui karakter fisik (tekstur) dan karakter kimia (kadar air, lemak, protein dan fenol) terhadap bakso ikan tenggiri citarasa asap yang paling disukai[6]. Rancangan yang digunakan variasi metode penambahan asap cair (pencampuran, pencelupan dan penyemprotan) serta variasi konsentrasi asap cair (3\%, 5\% dan 7\%). Analisis data secara statistik dengan ANOVA pada $\alpha=5 \%$ serta dilanjutkan dengan uji DMRT apabila ada beda nyata. Hasil penelitian menunjukkan bahwa variasi metode serta konsentrasi pemberian asap cair pada bakso ikan tenggiri tidak memberikan pengaruh beda nyata terhadap sifat sensori warna, kekenyalan serta keseluruhan tetapi memberikan pengaruh bervariasi terhadap sifat sensori aroma asap dan rasa asap. Sebelumnya, juga pernah dilakukan penelitian yang bertujuan menentukan tingkat konsentrasi yang dapat menghambat pertumbuhan jamur Phytophthora sp. dan pengaruhnya terhadap jumlah sporangium dan klamidospora. Penelitian ini menggunakan Rancangan Acak Lengkap yang terdiri atas perlakuan asap cair tempurung kelapa pada konsentrasi antara 0\% - 34\%. Analisis statistik menunjukkan LC50 dalam penelitian ini adalah sebesar 0,11\%. Hasilnya konsentrasi di atas LC50 secara nyata menekan pembentukan sporangium dan klamidospora[7]. Telah dilakukan penelitian dengan tujuan untuk evaluasi efektivitas asap cair dalam menurunkan kadar logam berat $\mathrm{Pb}$ pada biji kedelai. Parameter yang diamati adalah penurunan kadar $\mathrm{Pb}$ pada biji kedelai. Hasil penelitian menunjukkan bahwa semakin tinggi konsentrasi asap cair yang digunakan untuk perendaman maka penurunan kadar logam berat $\mathrm{Pb}$ juga semakin besar[8]. Terdapat penelitian yang bertujuan mengidentifikasi komponen senyawa volatil di dalam asap cair tempurung kelapa hibrida hasil fraksinasi pada berbagai suhu redistilasi. Fraksinasi asap cair kasar di dalam penelitian ini dilakukan dengan redistilasi bertingkat serta prekondensasi dengan tiga variasi suhu : $<100{ }^{\circ} \mathrm{C} ; 100-110{ }^{\circ} \mathrm{C}$ dan $>110{ }^{\circ} \mathrm{C}$. Hasil penelitian menunjukkan bahwa redisti- lasi asap cair pada suhu $100-110{ }^{\circ} \mathrm{C}$ mempunyai total rendemen tertinggi yakni $85,70 \%$. Kisaran aroma asap hasil fraksinasi dengan redistilasi bertingkat mempunyai kisaran aroma kuat sampai dengan sangat kuat/menyengat. Hasil pengujian dengan GC-MS menunjukkan bahwa asap cair kasar mengandung 42 senyawa organic, dan senyawa yang berperan di dalam aroma asap cair adalah senyawa fenol, derivat guaiakol, derivat syringol, isoeugenol[9]. Sementara itu, telah dilakukan penelitian untuk mengetahui pengaruh konsentrasi asap cair kayu karet dan tempurung kelapa terhadap pengurangan polusi udara pada lump. Parameter yang dianalisis pada asap cair meliputi $\mathrm{pH}$, kandungan total phenol, kandungan total asam, dan komponen senyawa penyusun asap cair. Pada lump yang diamati adalah $\mathrm{pH}$ penggumpalan, uji organoleptik bau, kandungan $\mathrm{NH} 3$ dan kadar karet kering (KKK). Hasil penelitian menunjukkan asap cair kayu karet mempunyai kandungan total asam yang lebih tinggi daripada asap cair tempurung kelapa, tetapi mempunyai kandungan senyawa phenol yang lebih rendah daripada asap cair tempurung kelapa. Sebagai koagulan, asap cair kayu karet 15\% dan asap cair tempurung kelapa 10\% menghasilkan mutu lump yang baik dengan gumpalan sempurna tidak berbau busuk dan mempunyai KKK kategori mutu 1, yang memenuhi spesifikasi persyaratan mutu SNI 06-2047- 2002. Kualitas lump yang dihasilkan lebih baik daripada penggunaan asam format (koagulan rekomendasi), terutama dalam menangani polusi udara pada lump. Dengan demikian, asap cair kayu karet maupun asap cair tempurung kelapa merupakan koagulan ramah lingkungan[10]. 


\section{Simpulan}

Dari uraian di atas dapat disimpulkan bahwa perlu peningkatan manajemen sehingga mampu menerapkan standar kualitas dan penambahan pendapatan melalui produksi asap cair berkualitas tinggi untuk mendukung program biogasoline. Hasilnya, pengerajin mampu menghasilkan asap cair dengan kualitas yang jauh lebih baik daripada sebelumnya, dan mampu menambah pendapatan kurang lebih sebesar 4 kali lebih besar, yaitu dari sebelumnya harga asap cair sebesar Rp 6.000,00 per liter, menjadi Rp 28.000,00 setelah dilakukan proses destilasi.

\section{Ucapan Terima Kasih}

Ucapan Terima Kasih Kepada Lembaga Penelitian Publikasi dan Pengabdian Kepada Masyarakat Universitas Muhammadiyah Yogyakarta, No. SK 031/PEN-LP3M/I/2020 tanggal 20 Januari 2020. Ucapan terima kasih juga diberikan kepada Kelompok Pengrajin Arang Batok "Maju Adil Makmur", Agus Winarno, Sriyatun, yang memberikan sumbangan berarti dalam program ini.

\section{Daftar Pustaka}

S. Jamilatun and M. Setyawan Program Studi Teknik Kimia Fakultas Teknologi Industri Universitas Ahmad Dahlan Yogyakarta JlProf DrSoepomo, "Pembuatan Arang Aktif dari Tempurung Kelapa dan Aplikasinya untuk Penjernihan Asap Cair." Accessed: Oct. 25, 2020. [Online]. Available: http://wartawarga.gunadarma.ac.id/2009/12/tugas-iad-3tekhnologi-energi.

I. Isa, W. J. A. Musa, and S. W. Rahman, "Pemanfaatan Asap Cair Tempurung Kelapa Sebagai Pestisida Organik Terhadap Mortalitas Ulat Grayak (Spodoptera Litura F.)," Jamb.J.Chem, no. 1, pp. 15-20, 2019, Accessed: Oct. 25, 2020. [Online]. Available: https://core.ac.uk/download/pdf/233374608.pdf.

S. Budijanto, R. Hasbullah, ... S. P.-J. I. P., and undefined 2008, "Kajian keamanan asap cair tempurung kelapa untuk produk pangan,” journal.ipb.ac.id, Accessed: Oct. 25, 2020. [Online]. Available: http://journal.ipb.ac.id/index.php/JIPI/article/view/6475.

E. Himawati, "Pengaruh penambahan asap cair tempurung kelapa destilasi dan redestilasi terhadap sifat kimia, mikrobiologi, dan sensoris ikan pindang Layang (Decapterus spp)," 2010, Accessed: Oct. 25, 2020. [Online]. Available: https://digilib.uns.ac.id/dokumen/detail/16522/Pengaruh-penambahan-asap-cairtempurung-kelapa-destilasi-dan-redestilasi-terhadap-sifat-kimia-mikrobiologi-dansensoris-ikan-pindang-layang-decapterus-spp-selama-penyimpanan.

T. Sundari, "Potensi asap cair tempurung kelapa sebagai alternatif pengganti hidrogen peroksida (H2O2) dalam pengawetan ikan tongkol (Euthynnus affinis)," 2009, Accessed: Oct. 25, 2020. [Online]. Available: https://digilib.uns.ac.id/dokumen/detail/9805/Potensi-asapcair-tempurung-kelapa-sebagai-alternatif-pengganti-hidrogen-peroksida-H2O2-dalampengawetan-ikan-tongkol-Euthynnus-affinis.

N. Parnanto, W. A.-J. T. H. Pertanian, and undefined 2010, "Diversifikasi dan karakterisasi citarasa bakso ikan tenggiri (scomberomus commerson) dengan penambahan asap cair tempurung kelapa." Accessed: Oct. 25, 2020. [Online]. Available: https://jurnal.uns.ac.id/ilmupangan/article/download/13612/11356.

E. Pangestu, I. Suswanto, and S. S.-P. dan L. Tropika, "Uji Penggunaan Asap Cair Tempurung Kelapa dalam Pengendalian Phytophthora SP. Penyebab Penyakit Busuk Buah Kakao secara In Vitro." Accessed: Oct. 25, 2020. [Online]. Available: https://www.neliti.com/publications/220714/uji-penggunaan-asap-cair-tempurung-kelapa- 
dalam-pengendalian-phytophthora-sp-pen.

S. Hartati, P. Darmadji, and Y. Pranoto, "PENGGUNAAN ASAP CAIR TEMPURUNG KELAPA UNTUK MENURUNKAN KADAR TIMBAL (Pb) PADA BIJI KEDELAI (Glycine max)," 2015.

S. Kadir, P. Darmadji, and C. Hidayat, "FRAKSINASI DAN IDENTIFIKASI SENYAWA VOLATIL PADA ASAP CAIR TEMPURUNG KELAPA HIBRIDA Fractionation And Identification Of Volatile Compounds In Liquid Smoke From Hybrid Coconut Shell," 2010.

J. Towaha, A. Aunillah, dan Eko Heri Purwanto Balai Penelitian Tanaman Industri dan Penyegar Jalan Raya Pakuwon km, and S. Indonesia, "PEMANFAATAN ASAP CAIR KAYU KARET DAN TEMPURUNG KELAPA UNTUK PENANGANAN POLUSI UDARA PADA LUMP UTILIZATION OF RUBBER WOOD LIQUID SMOKE AND COCONUT SHELL LIQUID SMOKE TO REDUCE AIR POLLUTION IN THE LUMP PROCESSING," 2013. Accessed: Oct. 25, 2020. [Online]. Available: http://repository.pertanian.go.id/handle/123456789/2492. 